\title{
Challenges in Image-Guided Drainage of Infected Pleural Collections: A Review
}

\author{
Ashu S. Bhalla ${ }^{1}$ Manisha Jana ${ }^{1} \quad$ Priyanka Naranje ${ }^{1}$ Swish K. Singh ${ }^{1} \quad$ Irshad Banday ${ }^{1}$ \\ ${ }^{1}$ Department of Radiodiagnosis, All India Institute of Medical \\ Sciences, Ansari Nagar, New Delhi, Delhi, India \\ Address for correspondence Priyanka Naranje, MD, DNB, MNAMS, \\ Department of Radiodiagnosis, All India Institute of Medical Sciences, \\ J Clin Interv Radiol ISVIR 2022;6:131-140. \\ Ansari Nagar, New Delhi, 110029, Delhi, India \\ (e-mail: priyanka11sh@gmail.com).
}
Abstract
Keywords
- pleural effusion
- empyema
- image guided drainage
- drainage
- pigtail drainage

Infected pleural fluid collections (IPFCs) commonly occur as a part of bacterial, fungal, or tubercular pneumonia or due to involvement of pleura through hematogenous route. Management requires early initiation of therapeutic drugs, as well as complete drainage of the fluid, to relieve patients' symptoms and prevent pleural fibrosis. Imageguided drainage plays an important role in achieving these goals and improving outcomes. Intrapleural fibrinolytic therapy (IPFT) is also a vital component of the management. The concepts of image-guided drainage procedures, IPFT, and nonexpanding lung are discussed in this review.

\section{Introduction}

Infected pleural fluid collections (IPFCs) can be the result of various organisms, the most frequent being bacterial or mycobacterial (tubercular), much less frequently fungal, and are rare in viral infections. This article focuses on IPFCs associated with bacterial pneumonia. In other forms of IPFCs caused by organisms, such as tuberculosis/fungi, basic presentation and treatment remain the same but recommendations may vary in terms of time of intervention. IPFCs associated with bacterial pneumonia may develop in the setting of community-acquired pneumonia (CAP), as well in hospital-acquired pneumonia (HAP). Pneumonia can be complicated by parapneumonic effusion, complicated parapneumonic effusion (CPE), or empyema which are defined subsequently. However, there are a significant number of cases of empyema or CPE that do not have an underlying pneumonia. Moreover, their bacteriologic spectra are not always similar. Other possible causes of empyema include hematogenous spread of infection and contiguous spread from subdiaphragmatic pathologies and trauma. ${ }^{1-4}$
Management of CPE or empyema requires early and complete drainage, not only to relieve the patient's symptoms but also to prevent long-term complications of pleural fibrosis, resulting in compromised pulmonary function. Notable existing guidelines in terms of management include those of the British Thoracic Society (BTS) ${ }^{5}$ and American Academy for Thoracic Surgeons (AATS). ${ }^{6}$ The purpose of this review is to highlight key concepts and knowledge essential for optimal interventional radiology (IR) management of CPEs and empyema, to improve short- and long-term patient outcomes.

\section{Diagnosis and Terminology}

A concept that needs to be understood is that not all infected pleural fluid collections are empyemas. These could also be complicated parapneumonic/synpneumonic effusions. The differences between these two entities are illustrated in - Table 1. ${ }^{7-10}$ Further, terms which are employed are related to the clinical settings in which the empyema occurs. These are very similar to the settings of the underlying pneumonia. For example, CPE occurs as a complication of published online October 12, 2021
DOI https://doi.org/ 10.1055/s-0041-1734374. ISSN 2457-0214. (c) 2021. Indian Society of Vascular and Interventional Radiology. All rights reserved.

This is an open access article published by Thieme under the terms of the Creative Commons Attribution-NonDerivative-NonCommercial-License, permitting copying and reproduction so long as the original work is given appropriate credit. Contents may not be used for commercial purposes, or adapted, remixed, transformed or built upon. (https://creativecommons.org/ licenses/by-nc-nd/4.0/)

Thieme Medical and Scientific Publishers Pvt. Ltd., A-12, 2nd Floor, Sector 2, Noida-201301 UP, India 
Table 1 Differences between empyema and complicated parapneumonic effusion

\begin{tabular}{|l|l|l|}
\hline & Definition & Pitfalls/fallacies $^{7-10}$ \\
\hline Empyema & $\begin{array}{l}\text { Pleural collection, } \\
\text { containing either } \\
\text { - Pus } \\
\text { - Culture/gram } \\
\text { stain positive } \\
\text { fluid }\end{array}$ & $\begin{array}{l}\text { - Glucose }<40 \\
\text { mg/dL suggestive } \\
\text { of empyema } \\
\text { - However, labora- } \\
\text { tory results not } \\
\text { always foolproof; } \\
\text { clinical context } \\
\text { should be taken } \\
\text { into consideration }\end{array}$ \\
$\begin{array}{l}\text { Complicated } \\
\text { effuprasion }\end{array}$ & $\begin{array}{l}\text { Clinical evidence of } \\
\text { infection, and } \\
\text { pleural fluid } \\
\text { collection with the } \\
\text { following features: } \\
\text { pH }<7.2 \text { or } \\
\text { Glucose }<60 \\
\text { mg/dL }\end{array}$ & $\begin{array}{l}\text { - Laboratory values } \\
\text { may be variable } \\
\text { pH may be } \\
\text { elevated by } \\
\text { urease-producing } \\
\text { organisms such as } \\
\text { Proteus }\end{array}$ \\
& \multicolumn{2}{|l}{} \\
\hline
\end{tabular}

CAP, while health care associated empyema (HCAE) is associated with HAP.

While the detection of IPFCs is largely clinical \pm imaging based, the diagnosis of empyema versus CPE relies largely on the pleural fluid aspiration. Pleural effusions associated with an underlying pneumonia should have a diagnostic tap, if the pneumonia does not respond to 48 to 72 hours of antibiotic treatment. ${ }^{5,11}$ A diagnostic tap should also be performed if a patient with sepsis has a pleural fluid of $>10-\mathrm{mm}$ thickness on chest radiograph/ultrasound or $>20 \mathrm{~mm}$ on computed tomography $(\mathrm{CT})^{6}$; or in elderly patients. The aspirated fluid may be serous/serosanguinous or frank pus. The analysis of pleural fluid has two components: biochemical and microbiological.

Biochemical analysis depends on pleural fluid $\mathrm{pH}$, glucose, and lactate dehydrogenase (LDH). It should be kept in mind that the yield of pleural fluid in cases of CPE may only be approximately $50 \%$, whereas blood cultures are reported to have higher yield. Whenever possible, blood culture specimens should also be obtained. Several ways have been described to enhance the microbiological yield of pleural fluid, such as direct inoculation of the pleural fluid, into a blood culture bottle after aspiration at the bedside. Another method is adopting Polymerase chain reaction (PCR) technique for pleural fluid samples/biopsy. This is especially useful for anaerobes. However, since the microbiological confirmation rate is markedly low, empiric antibiotic therapy is often started depending on the specific clinical scenario. Microbiological analysis of empyema/CPE fluid may yield variable bacteriologic spectra. While Streptococcus predominates the CAP fluid, methicillin-resistant Staphylococcus aureus (MRSA) and gram negative and anaerobic bacteria constitute a large part in HCAE. ${ }^{10,12,13}$

\section{Imaging of Infected Pleural Fluid Collections}

While the complete discussion of this topic is beyond the scope of this review, imaging is critical in detection, quantification, guiding drainage, and follow-up.
Table 2 Quantification of IPFCs on imaging

\begin{tabular}{|l|l|}
\hline Modality & Technique \\
\hline USG & $\begin{array}{l}\text { The Goecke } 2 \text { formula } \\
\text { "Estimated volume (EV) } \\
\mathrm{mL}=(\mathrm{X}+\mathrm{LDD}) \times 70 \text { " }\end{array}$ \\
\hline CT & $\begin{array}{l}\text { Mild: } 3 \mathrm{~cm} \\
\text { Moderate: } 3-10 \mathrm{~cm} \\
\text { Large: }>10 \mathrm{~cm}\end{array}$ \\
\hline $\begin{array}{l}\text { AP depth at } \\
\text { midclavicular line }\end{array}$ & $\begin{array}{l}\text { Mild: first quartile }(0-25 \%) \\
\text { Moderate: second (25-50\%) } \\
\text { Large: third (50-75\%) and } \\
\text { fourth (75-100\%) }\end{array}$ \\
\hline AP quartile
\end{tabular}

Abbreviations: AP, anteroposterior; CT, computed tomography; IPFC, infected pleural fluid collection; LDD, lung to diaphragm distance; USG, ultrasonography.

\section{Quantification of Pleural Fluid Collection}

Quantification of pleural fluid guides the decision for drainage. Pleural effusions can be quantified on ultrasound and CT using various methods which are summarized in - Table 2 . On ultrasound, the Goecke 2 formula measured in erect position of the patient is reported to most closely correlate with actual fluid drained. Ultrasonography (USG) image is obtained keeping probe longitudinally oriented along dorsolateral/posterolateral aspect of chest wall, and craniocaudal extent $(\mathrm{X})$ and the lung base to middiaphragm distance (LDD)/subpulmonary height is measured. Volume of effusion is measured using formula "estimated volume (EV) $\mathrm{mL}=(\mathrm{X}+\mathrm{LDD}) \times 70^{\prime 14}$ (-Fig. 1A-D).

Computed tomography: one method is to measure anteroposterior (AP) depth at the midclavicular line on axial CT image where the maximum fluid is seen and quantify according to - Table 2 (-Fig. 1E). Another method is to divide hemithorax in a quartile wherein first AP quartile represents 0 to $25 \%$ fluid occupying the hemithorax and suggest effusions are small, second AP quartile represents 25 to $50 \%$ effusions that are moderate, and third 50 to $75 \%$ or fourth 75 to $100 \%$ AP-quartile effusions are large ${ }^{15}$ (-Fig. 1F). CT volumetry software tool may also be used for estimation.

\section{Staging of Infected Pleural Fluid Collection}

Empyema is diagnosed on CT when there is a pleural fluid collection with enhancing visceral and parietal pleural layers, giving rise to "split pleura sign." Classically, IPFC has been divided into three stages; exudative phase, fibrinopurulent stage, and empyema stage. ${ }^{16} \mathrm{CT}$ findings indicating the stages ${ }^{17}$ are shown in - Table 3 and -Fig. 2. CPE on USG may appear as clear fluid or fluid with fine internal echoes and on CT may show early pleural thickening.

However, the imaging findings may not always correspond to empyema in pleural fluid analysis. The final diagnosis is made by thoracentesis. Sinusoid sign on USG represents the appearance of wavy pattern on M-mode demonstrated when the visceral and parietal pleura are separated by free fluid (-Fig. 3). It may be absent when there is a dense or multiseptated collection. 


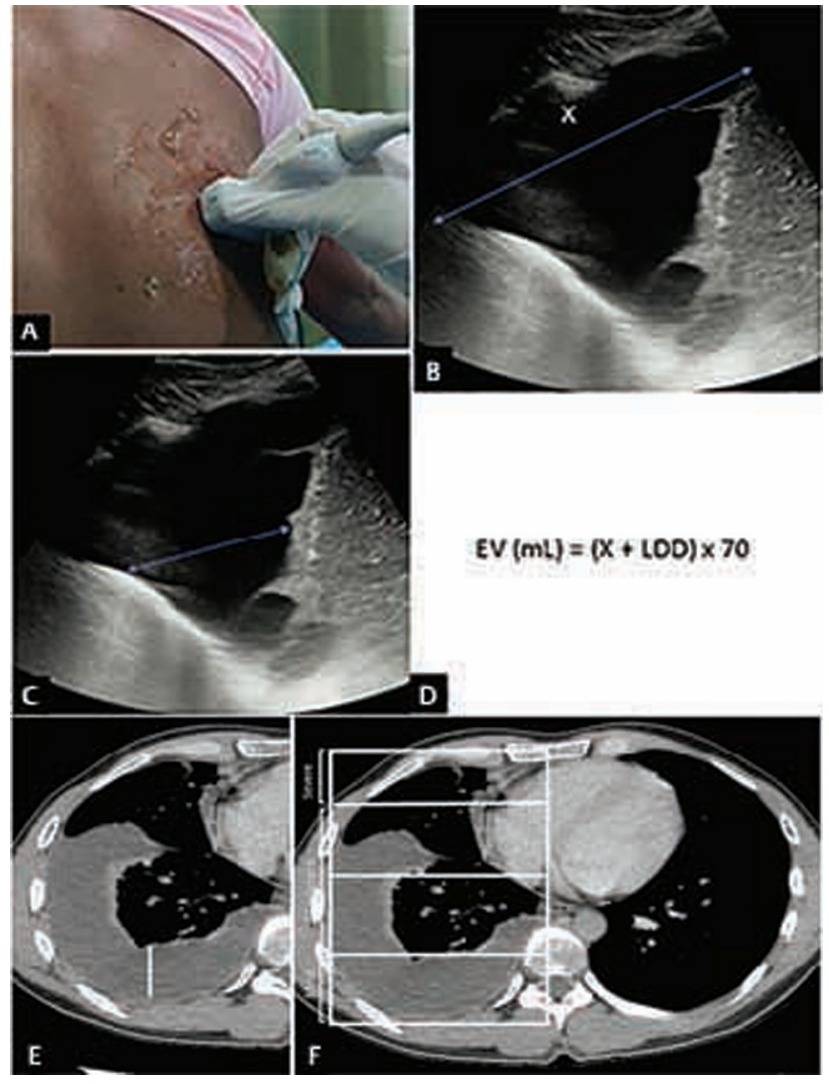

Fig. 1 Quantification techniques of pleural effusion. (A-D) Ultrasound quantification (A) Probe position on dorsolateral aspect in erect/sitting position; (B) Image showing measurement of X, craniocaudal extent in centimeter of the effusion; (C) Lung to diaphragm distance (LDD), lung base to middiaphragm distance/subpulmonary height of the effusion (cm); and (D) Formula used to calculate the volume. (LDD: lung base to middiaphragm distance) $\mathrm{EV}$ is the estimated effusion volume $(\mathrm{mL})$ and 70 is the empirical factor/constant. (E and F) Computed tomography (CT) quantification technique of pleural effusion. (E) Anteroposterior (AP) depth of the pleural effusion at mid clavicular line where the maximum fluid is seen; and (F) Axial CT image with superimposed AP quartiles dividing the hemithorax to quantify the pleural effusion into mild, moderate and severe categories. CT showing right moderate effusion (Occupying 25th to 75th quartile of the right hemithorax).

\section{Management}

Management of IPFCs has two main modalities: surgery and percutaneous intervention (tube drainage and intrapleural fibrinolytic therapy [IPFT]). Most available literature sug-

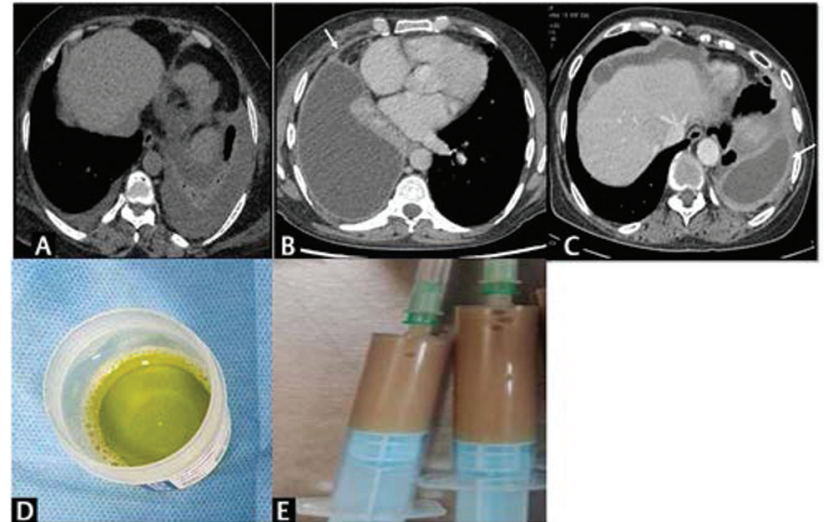

Fig. 2 Characterization of pleural effusion on CT. (A) Exudative phase-dependent, biconcave free fluid in pleural space, consolidation in left lung. (B) Fibrinopurulent phase-biconvex collection with smooth enhancing pleural thickening (split pleura sign). Edema of extrapleural soft tissue (arrow). (C) Organized phase showing residual fluid with left pleural thickening (arrow) and mild volume loss of hemithorax with rib crowding. (D, E) Types of aspirated pleural fluid. (D) Serous-clear straw colored fluid in exudative phase; (E) Pus-thick turbid fluid in fibrinopurulent phase.

gests surgery as the second line management option, after failure of conservative management or tube thoracostomy. Exceptions to this are presence of sepsis or septic shock or a suspected lung abscess. Very few trials analyzed the efficacy of upfront minimally invasive video-assisted thoracic surgery (VATS) in comparison to tube drainage. ${ }^{18}$ This article will describe the interventional management: goals of treatment are two folds, relieving sepsis and preventing longterm complications (e.g., fibrosis and trapped lung).

\section{Time to Intervene}

Timing and nature of surgery is beyond the scope of this article. Interventional management is discussed here. However, not every parapneumonic effusion needs drainage. If the effusion is mild and the patient is responding to antibiotics, it should not be drained. Unlike diagnostic tap, no volume cut-off is available for IPFT.

Parapneumonic effusion has classically been described to evolve through three stages: exudative, fibrinopurulent, and organizing. ${ }^{19}$ The time duration of each stage is variable, and delay in thoracentesis may result in increased morbidity. The diagnostic thoracentesis should be performed proactively in

Table 3 CT findings indicative of various stages of IPFC

\begin{tabular}{|c|c|c|c|}
\hline Stages & Exudative stage & Fibrinopurulent stage & Organizational stage \\
\hline CT findings & $\begin{array}{l}\text { - Dependent, biconcave free fluid } \\
\text { in pleural space } \\
\text { - Consolidation in ipsilateral lung } \\
\text { - No or mild pleural enhancement }\end{array}$ & $\begin{array}{l}\text { - Parietal pleural thickening is } \\
\text { always present } \\
\text { - Split pleura sign present } \\
\text { - Loculations } \\
\text { - Biconvex/lenticular shape } \\
\text { - Internal septations } \\
\text { - Air foci/air-fluid level } \\
\text { (hydropneumothorax) } \\
\text { - Edema of extrapleural soft tissue }\end{array}$ & $\begin{array}{l}\text { - Smooth grossly thickened pleura } \\
\text { - Residual fluid may be present } \\
\text { - Pleural calcification } \\
\text { - Extrapleural fat proliferation } \\
\text { - Volume loss of hemithorax with } \\
\text { rib crowding }\end{array}$ \\
\hline
\end{tabular}

Abbreviations: CT, computed tomography; IPFC, infected pleural fluid collection. 

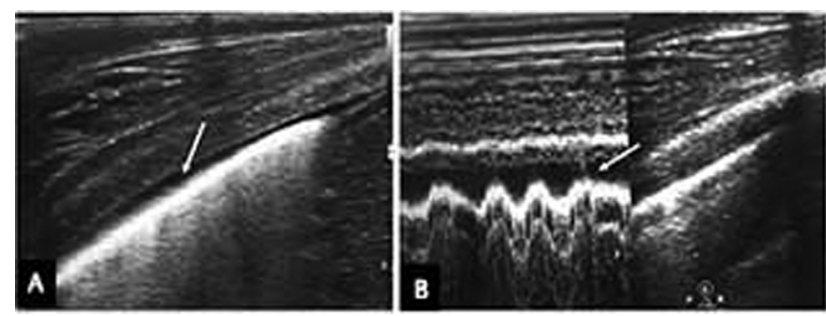

Fig. 3 Sinusoid sign. (A) Ultrasound showing minimal pleural effusion (arrow). (B) In same patient, $M$ mode showing presence of sinusoid sign (arrow).

the earliest suspicion of nonresponse to antibiotics (see "Diagnosis and Terminology"). Similarly, a tube thoracostomy should also be performed at an early stage of the disease, so as to avoid subsequent complications. ${ }^{20,21}$

\section{Tube Drainage}

While surgical drainage enables one to use larger bore tubes (up to $32-40 \mathrm{Fr}$ ), image-guided drainage is typically described to suffer from the drawback of smaller size of the tubes. Though there is no consensus on the size of the optimal chest tube for drainage, for most IPFCs, a smallbore catheter of size 10 to $14 \mathrm{~F}$ will be adequate. With the advances in percutaneous drainage tube technology, larger bore tubes, even up to 32 Fr (Thal-Quick, Cook Medical, United States), ${ }^{22}$ are now available and can be used for thick stubborn collection not responding to small bore catheter drainage. In cases with rib crowding, it is advisable to measure the intercostal space and calculate tube size accordingly. Pigtail catheter is commonly preferred due to the presence of multiple side holes. Malecot catheter is also another preferred self-retaining drainage catheter.

Technique principles of standard trocar and Seldinger's techniques of tube insertions are similar to all drainage procedures elsewhere in the body. Complete discussion of the techniques is beyond the scope of this review. A few points specific to thoracic drainage are emphasized. Standard site of catheter insertion is along the midaxillary line in fifth or sixth intercostal space and direction of insertion being superior to inferior. However in case of loculated effusions, such universal approach will have to be modified according to site of loculation. Care should be taken that no air is introduced into the pleural space during entire procedure and use of three ways are helpful. After the catheter is placed, it should be connected to an underwater seal drainage bag. USG along with fluoroscopy is a good combination modality for guiding the procedure. CT also can be adapted accordingly, especially in case of rib crowding and when USG visualization is poor.

Outcome of empyema having frank pus vis-a-vis CPE may not be largely different. Whereas it has been demonstrated that frank pus does not essentially imply a tube thoracostomy failure, absence of pus is usually associated with a good outcome of tube thoracostomy. ${ }^{21-26}$ Larger bore tubes have higher pain scores but offer no additional advantage in terms of prevention of surgical intervention or mortality.

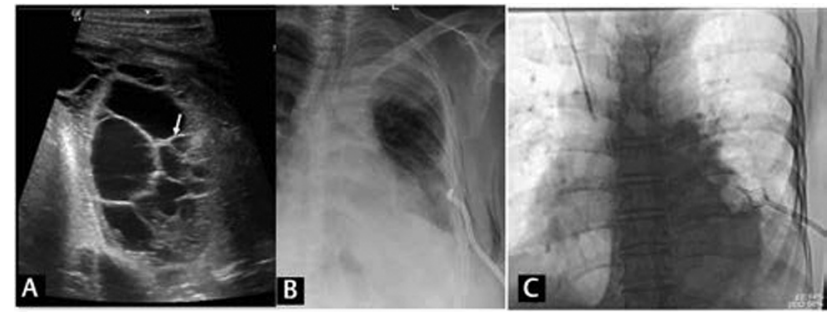

Fig. 4 Failure of tube drainage. (A) Ultrasonography (USG) showing multiple loculations due to thick septations (arrow). (B) Frontal CXR showing catheter tip at the level of lateral thoracic wall suggestive of displaced drain. (C) Postdisplacement, Malecot catheter was inserted.

Catheter removal: although literature states, for removal of tube, the output volume to be $200 \mathrm{ml} /$ day in general, ${ }^{27}$ the decision of tube removal in clinical practice is based on combination of factors such as radiological reduction in size of pleural fluid collection, clinical resolution of sepsis, and fever with no significant drainage output for 48 to 72 hours. Hence, the catheter can be retained even with output $<200$ $\mathrm{mL} /$ day, as several of these collections do not have large volumes.

Reasons for inadequate drainage include thick, viscous collection and presence of loculations. Postinsertion monitoring consists of output monitoring, checking for any tube kink and regular flushing of the tube. Simple saline irrigation has been proven to be useful. ${ }^{28}$ It has been found superior to tube drainage alone. Thrice daily irrigation with $200 \mathrm{~mL}$ of saline for 3 days is recommended. ${ }^{28}$ Due to improper fixing or accidental misplacement, there may be tube displacement (-Fig. 4). Repeat chest X-ray (CXR) can be helpful. In the authors' experience, a low-dose CT can be used in the followup before repositioning of catheters.

\section{Intrapleural Fibrinolytic Therapy}

While IPFT forms an important component in the management of IPFCs, their use is very variable among institutions. This topic will be discussed under the following headings: Indications, choice of pharmacologic agent, benefits, adverse effects, and cost-effectiveness issues.

\section{Indications}

The primary indication for IPFT is organizing phase of empyema with loculations and fibrin deposition which may not resolve completely with tube thoracostomy alone; resulting in nonexpansion of underlying lung. IPFT aims to lyse the loculations caused by fibrin deposition.

\section{Choice of Pharmacologic Agent}

Streptokinase/urokinase are the pharmacologic agents used in the earlier trial (multicenter intrapleural sepsis trial [MIST] 1). In comparison to placebo, they were not found to have any improved outcome (in terms of death, surgical referral or duration of hospital stay). Tissue plasminogen activator (tPA) acts by virtue of its fibrinolytic property. It can either be used alone or in combination with other agents. The viscosity of empyema fluid is caused by extracellular DNA. Deoxyribonuclease (DNase) is another agent which acts by 


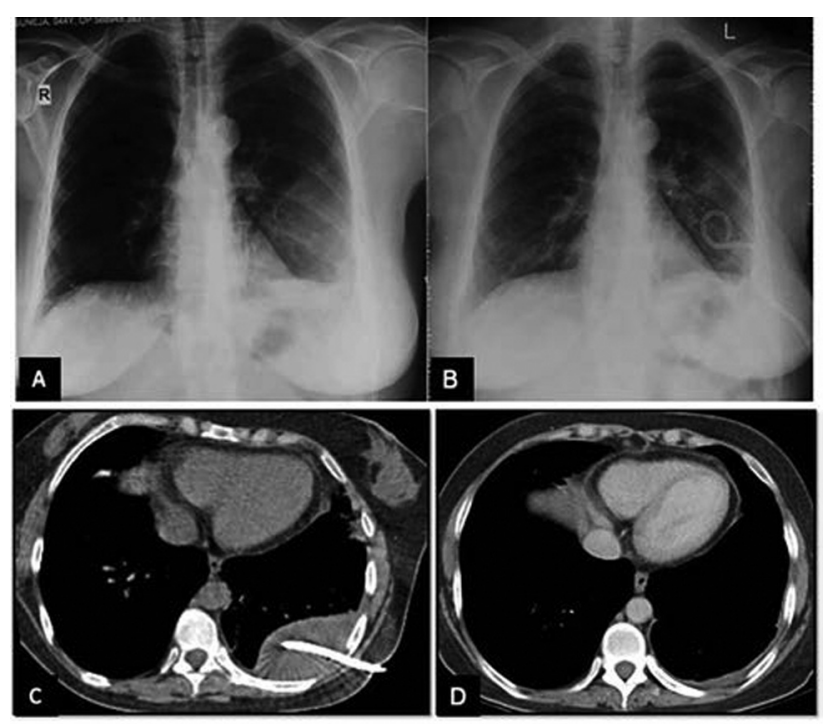

Fig. 5 Benefits of fibrinolytic agents. (A-C) Pretreatment-chest $X$ ray $(C X R)$ and noncontrast computed tomography $(C T)$ showing loculated left pleural collection with pigtail in situ. However, the collection was not drained in spite of drain in situ. (D) Post-streptokinase treatment-Image at similar level showing complete resolution of collection.

degrading them. Also, they help destroy bacterial biofilm. DNase is reported to increase the efficacy of streptokinase or tPA. A combination of tPA and DNase was reported to be more effective than any other combinations with respect to a reduction of surgical referral and morbidity.

\section{Frequency and Dosage}

Various recommendations exist, ranging from 2 to $100 \mathrm{mg}$ of $\mathrm{tPA}^{29,30}$ for dwell time varying from 30 minutes to 4 hours. ${ }^{31,32}$ MIST2 trial recommends twice daily administration of a dose of $10 \mathrm{mg}$ of tPA and $5 \mathrm{mg}$ of DNase; instilled sequentially with a gap of 2 hours. Individual dwell time for each agent is 1 hour. In case of simultaneous administration of two agents; a dwell time of 2 hours should be allowed. The duration of treatment is also not uniform, and mostly individualized. However, a duration of 3 days is recom- mended by MIST2 trial; and any prolongation of treatment duration does not lead to improved outcome.

\section{Benefits}

Improved outcome of tube drainage in terms of reduced rate of surgical intervention and death (- Fig. 5).

\section{Adverse Effects}

Intrapleural administration of tPA does not cause systemic bleeding because they do not have significant systemic absorption. However, they can cause local (pleural) hemorrhage, especially at a higher dose. The maximum safe dose is variable according to different studies, ranging from 20 to $100 \mathrm{mg}$. Intrapleural hemorrhage is mostly treatable with conservative measures and stoppage of IPFT. Anaphylaxis to streptokinase is also a documented adverse effect which can be life threatening.

\section{Cost-Effectiveness Issues}

IPFT reduces the rates of surgical referral and, therefore, the surgical cost. However, the additional period of hospital stay and the cost of fibrinolytics should also be taken into consideration. A recent meta-analysis did not show any benefit of IPFT in terms of duration of hospital stay. ${ }^{33}$ This is more relevant in resource-constrained countries like India.

The summary of the pharmacologic agents and their dosage is further listed in - Table 4.

\section{Important Trials on Intrapleural Fibrinolytic Therapy}

The topic of the efficacy of IPFT is a matter of perpetual confusion. Several large studies/trials have taken place in the last few decades, a few of them are being discussed hereinafter.

\section{Multicenter Intrapleural Sepsis Trials 1 and $\mathbf{2}$}

These two large trials originated from the United Kingdom. MIST1 trial was conducted between 1999 and 2002 on 454 patients, with the objective of establishing the efficacy and safety of intrapleural streptokinase in patients of empyema and CPE. This study concluded that intrapleural streptokinase

Table 4 Comparison of pharmacologic agents for IPFT

\begin{tabular}{|l|l|l|l|}
\hline Agent name & Mechanism of action & Dosage & Side effects \\
\hline Streptokinase/urokinase & $\begin{array}{l}\text { Promotes fibrinolysis by } \\
\text { activation of plasmin }\end{array}$ & $\begin{array}{l}250,000 \text { units dissolved in } 30 \mathrm{~mL} \\
\text { saline and instilled through thora- } \\
\text { costomy tube once/twice daily for } \\
\text { six doses }\end{array}$ & $\begin{array}{l}\text { - Anaphylaxis (uncommon, with } \\
\text { streptokinase only, not } \\
\text { urokinase) } \\
\text { Generalized bleeding } \\
\text { tendencies }\end{array}$ \\
\hline tPA & $\begin{array}{l}\text { Activation of plasmino- } \\
\text { gen to form plasmin and } \\
\text { degrade fibrin }\end{array}$ & $\begin{array}{l}10 \mathrm{mg} \text { of t-PA through thoracos- } \\
\text { tomy tube, followed by a dwell } \\
\text { time of 1 hour. Twice daily for 3 } \\
\text { days }\end{array}$ & $\begin{array}{l}\text { - Local site pain } \\
\text { - Erythema/rash } \\
\text { - Intrapleural hemorrhage } \\
\text { - Hemoptysis }\end{array}$ \\
\hline DNAse & $\begin{array}{l}\text { Degrades bacterial bio- } \\
\text { film and reduces viscos- } \\
\text { ity of pus (it contains } \\
\text { extracellular DNA) }\end{array}$ & $\begin{array}{l}5 \mathrm{mg} \text { through thoracostomy tube, } \\
\text { followed by a dwell time of 1 hour. } \\
\text { Twice daily for 3 days }\end{array}$ & $\begin{array}{l}\text { - Local site pain } \\
\text { - Erythema/rash } \\
\text { - Intrapleural hemorrhage } \\
\text { - Hemoptysis }\end{array}$ \\
\hline
\end{tabular}

Abbreviations: DNase, deoxyribonuclease; IPFC, infected pleural fluid collection; tPA, tissue plasminogen activator. 

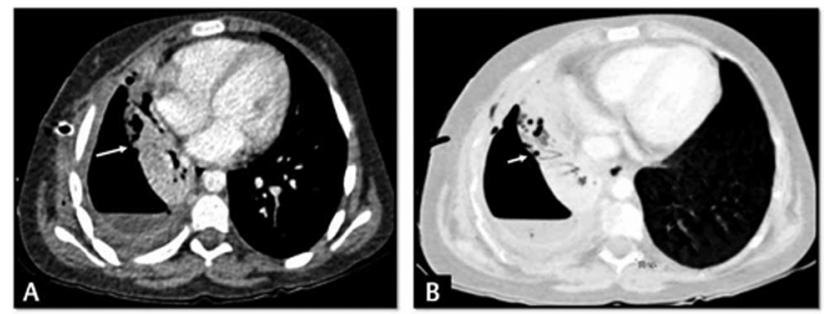

Fig. 6 Lung entrapment versus trapped lung: pathogenesis and clinical manifestations.

did not improve mortality, rate of surgery or length of the hospital stay, and was associated with significant adverse effects. ${ }^{24}$ MIST2 trial, conducted from 2005 to 2008, evaluated the efficacy of other intrapleural fibrinolytic agents (tPA and DNase) on 210 patients (-Supplementary Table S1; available in the online version). This trial had four arms (tPA alone, DNase alone, combination, and placebo). The investigators concluded that intrapleural t-PA-DNase therapy improved fluid drainage and reduced the frequency of surgical referral, and hospital stay. Treatment with DNase alone or t-PA alone was ineffective. ${ }^{25}$ Another meta-analysis comparing IPFT with placebo reported that IPFT reduces the need for surgical referral and low risk of overall mortality. ${ }^{34} \mathrm{~A}$ flowchart summarizing the indications for various intervention steps is depicted in -Fig. $\mathbf{6}$ :

\section{Special Situations}

\section{Bronchopleural Fistula}

Bronchopleural fistula (BPF) can develop after lung resections (commoner) and as a complication of necrotizing pneumonia (rare). The incidences of BPF after pulmonary resections have reduced with the advent of good antibiotics. The reported incidence of BPF is higher in cases of pneumonectomy rather than lobectomy. Several other factors govern the risk of developing a postoperative BPF.

A necrotizing pneumonia can occasionally give rise to BPF (-Fig. 7). Long-term tube thoracostomy is recommended. A word of caution worth mentioning is that in empyema associated with BPF, IPFT is contraindicated. Studies have demonstrated the utility of apposing the serratus anterior muscle in the chest cavity for the closure of fistula during thoracoscopic debridement in children. ${ }^{35}$

\section{Unexpandable Lung}

Unexpandable lung is a term used to define the condition when the visceral and parietal pleura do not appose even after adequate pleural fluid drainage. It can occur as a result of empyema, CPE, malignant pleural effusion, uremic effusion, hemothorax, and radiation-induced or pleurodesisinduced pleural damage.

The underlying mechanism of nonexpansion of lung can be as follows:

1. Central obstruction of the subtending bronchus (-Fig. 8A).

2. Prolonged atelectasis which leads to inadequate subsequent expansion (-Fig. 8B).
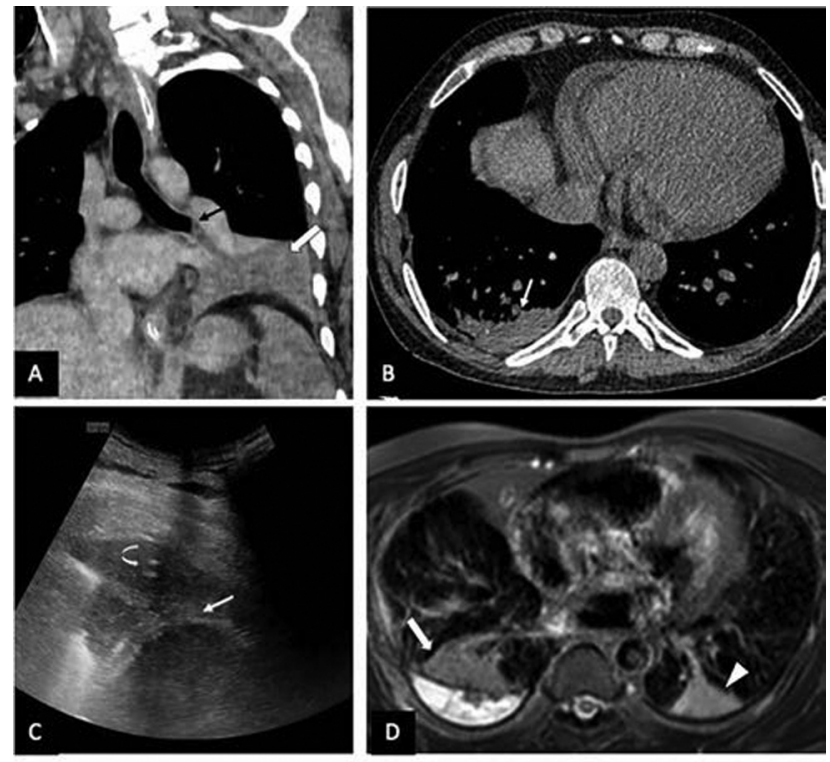

Fig. 7 Bronchopleural fistula. Few subpleural cysts communicating with pleural space: (A) mediastinal window; (B) lung window (arrow).

3. Thick pleural peel which hinders proper apposition of pleural layers ( - Fig. 8C and D ).

It is important to understand the difference between two terminologies used in relation to nonexpansion of the lung, "lung entrapment" and "trapped lung." Failure of apposition of pleural layers can be seen either during an active pleural inflammatory process (or malignancy) or in healed diseases where there is no active inflammation. The term "lung entrapment" is used when active inflammation is present while "trapped lung" is used in cases of healed infections. (-Fig. 9)

-Fig. 10 describes the pathogenesis and clinical manifestations of these two entities. Pleural manometry is useful in differentiating these two entities. Ultrasound demonstrates an absence of normal "sinusoid sign" in both these situations. CT is crucial in identifying the cause of nonexpansion.

The clinical manifestations arise out of the inability of the lung to expand. When a large amount of pleural fluid is drained, and yet the lung cannot expand, it creates a characteristic sharp pain. This pain has been typically described to resolve after injection of air into the pleural space ("therapeutic pneumothorax"). In case of a more pronounced negative intrapleural pressure, small peripheral airways may rupture, leading to pneumothorax ("pneumothoraxex-vacuo"). This pneumothorax is usually asymptomatic, as it is actually a way to normalize the negative pressure within the pleural cavity. Reexpansion pulmonary edema is also a dreaded complication of excessive pleural fluid drainage in the background of an unexpandable lung.

\section{Empyema in Children}

Incidence of CPE and empyema in children is lower than in adults. However, these are different from the adult 


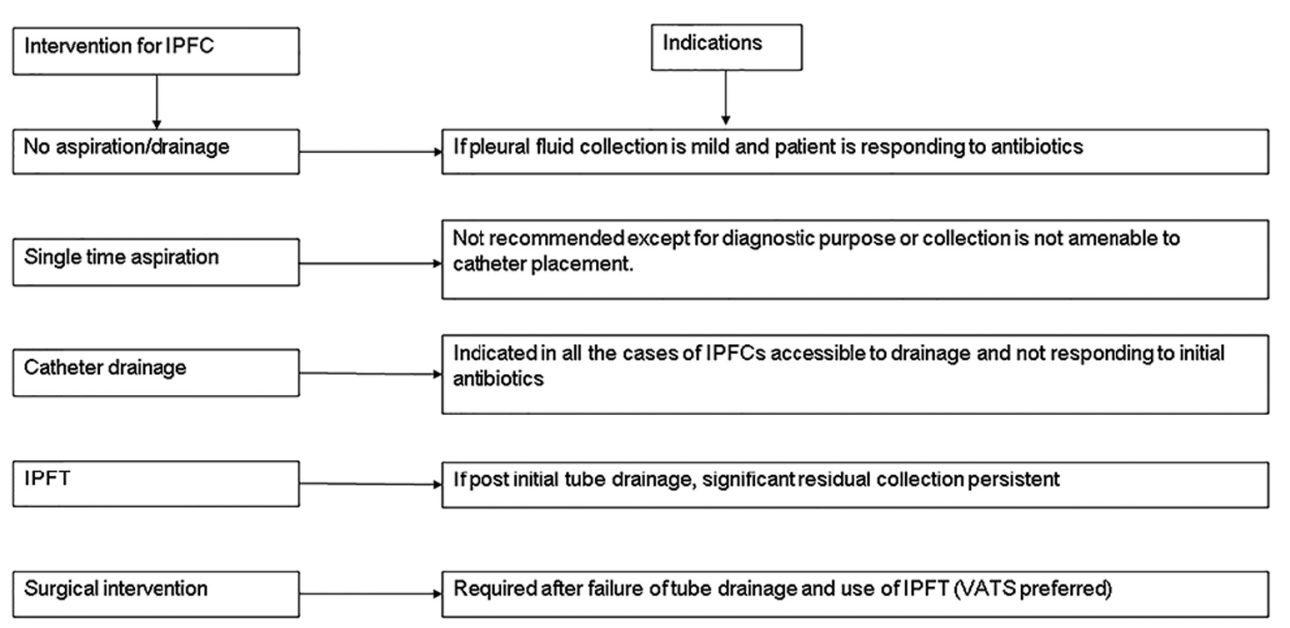

Fig. 8 Unexpanded lung (different patients) (A) Central obstruction: contrast-enhanced computed tomography (CECT) thorax oblique coronal image showing hypodense mucus plug (black arrow) causing complete occlusion of left main bronchus (LMB) which resulted in collapse of left lower lobe (black arrow); (B) Prolonged atelectasis (arrow) (C) Thick pleural peel (arrow) and collection with drain in situ (curved arrow). (D) Chest MRI (Short TI inversion recovery sequence (STIR) shows unexpanded segments of lung adjacent to chronic loculated pleural effusion/thickening on right side (arrow) and due to chronic atelectasis on left side (arrowhead).

counterpart, both in terms of epidemiology, as well as management strategies.

First, decision of tube thoracostomy is usually based on clinical (failure to respond to appropriate antibiotic treatment) and imaging parameters. CT is not routinely recommended. A baseline CT may be performed. However, USG is

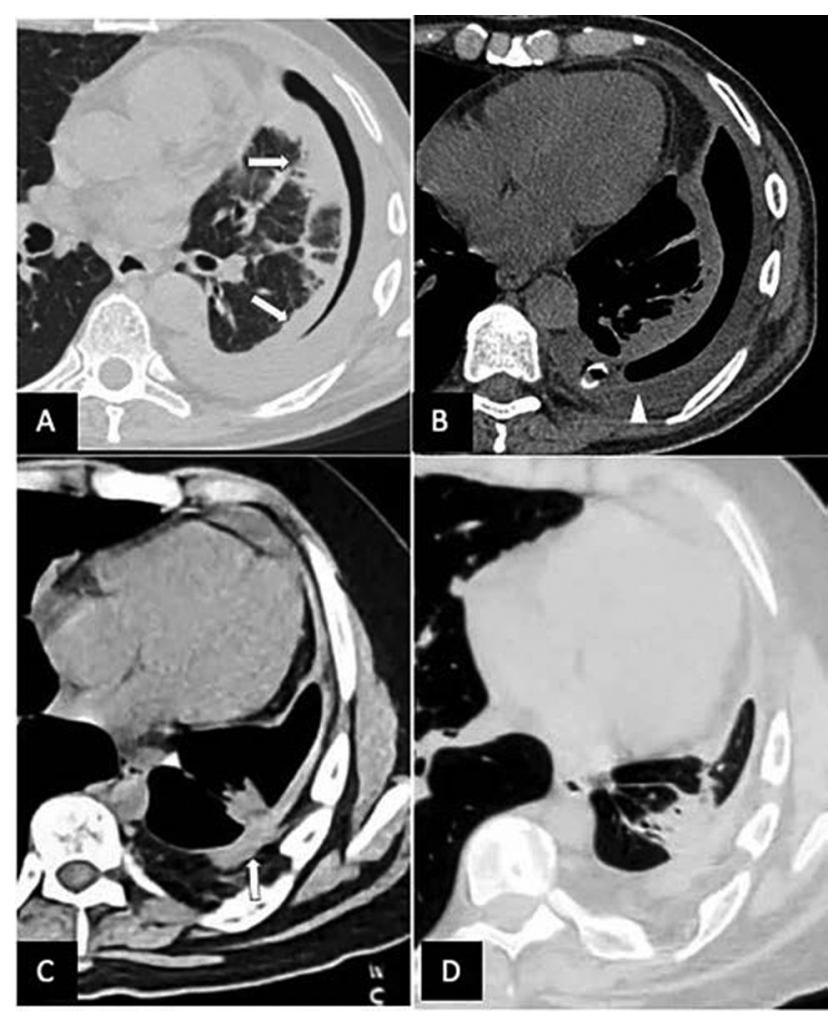

Fig. 9 (A, B) Lung entrapment: nonexpanded left lung parenchyma (arrow) due to pleural thickening and inflammation (arrowhead in B). Intercostal draining catheter is seen in situ; (C, D) Trapped lung: long standing pleural thickening without inflammation (arrow) resulting in left lung volume loss. preferred for monitoring. Echogenic contents, debris, loculations, and pleural thickening should call for escalation of management. In follow-up, USG is preferred as ultrasonographic visualization is much better in children owing to thinner chest wall musculature.

Second, the procedure of tube drainage should always be performed under proper sedation (in older children) and general anesthesia (in case of very small children). In case of procedure under sedation in an interventional radiology suite, proper patient monitoring should be ensured.

Third, there is no consensus recommendation regarding the optimal tube size in children. Several large studies have produced conflicting reports. ${ }^{35-38}$ In a large single-center study from the United Kingdom, ${ }^{39}$ smaller bore tubes were recommended in children. The advantages include superior patient comfort, less pain and reduced hospital stay. The same study has recommended a size of $8.5 \mathrm{Fr}$ for older children, ${ }^{39}$ and even smaller bore tubes in younger children.

Lastly, several technical nuances are worth noting in pediatric procedures. Single step trocar technique is often preferred over Seldinger's technique in children. ${ }^{37}$ The aspiration of pleural fluid should be gradual (maximum: $10 \mathrm{~mL} / \mathrm{kg}$ ) to avoid reexpansion pulmonary edema. In children, adhesive devices are preferred over sutures. Fibrinolytic dosage is also different in children. The recommended dose is $10,000 \mathrm{U}$ urokinase diluted in $10 \mathrm{~mL}$ of normal saline in infants and 40,000 U urokinase in $40 \mathrm{~mL}$ of normal saline in older children. A dwell time of 4 hours should be followed by an 8 -hour drainage at a negative suction of 10 to $20 \mathrm{~cm} \mathrm{H}_{2} \mathrm{O}$.

\section{Summary of Guidelines}

Several guidelines are available regarding diagnosis, management, and pharmacologic choices in IPFCs. Herein, we shall summarize the salient points from the AATS guidelines (-Table 5). 


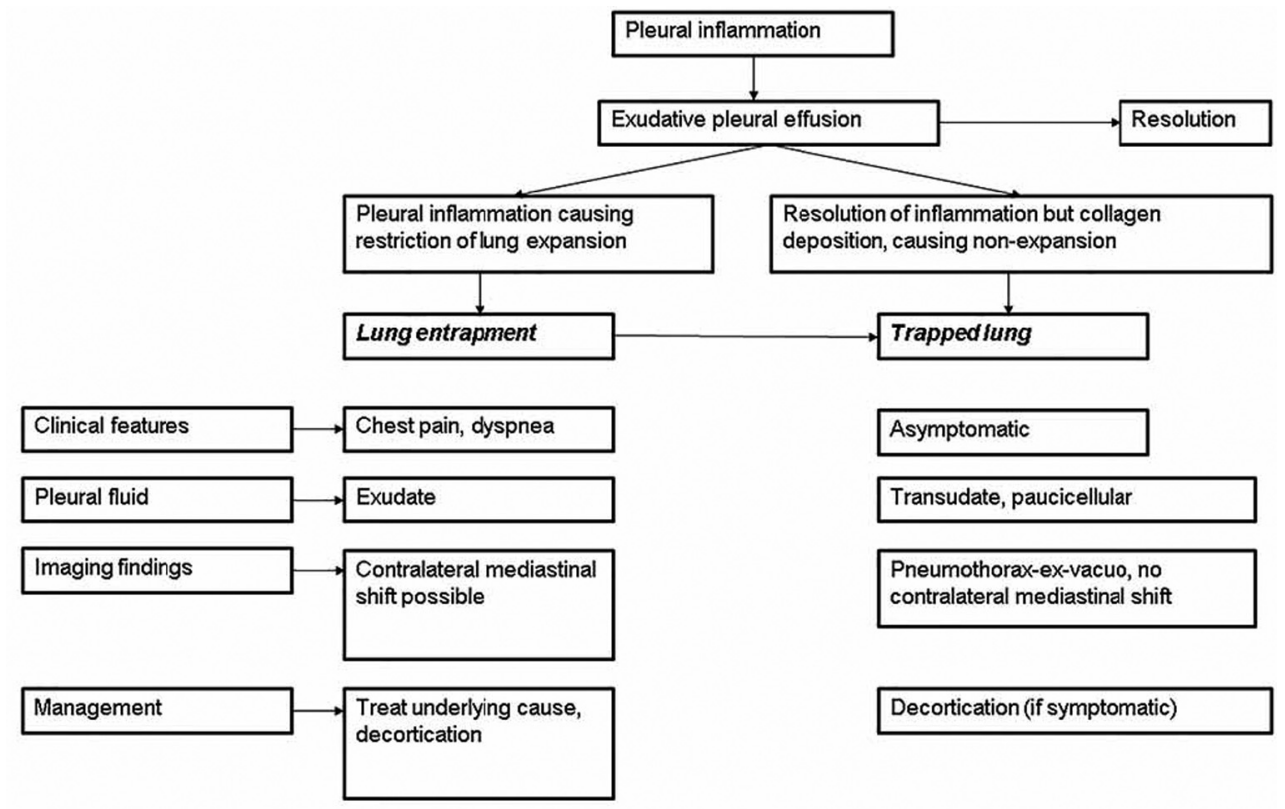

Fig. 10 Lung entrapment versus trapped lung: pathogenesis and clinical manifestations.

Table 5 Summary of recommendations according to AATS guidelines

\begin{tabular}{|c|c|c|c|c|}
\hline & Recommendations (class I) & $\begin{array}{l}\text { Recommendations } \\
\text { (class Ila) }\end{array}$ & $\begin{array}{l}\text { Recommendations } \\
\text { (class IIb) }\end{array}$ & $\begin{array}{l}\text { Not } \\
\text { recommended } \\
\text { (class III) }\end{array}$ \\
\hline $\begin{array}{l}\text { Clinical diagnosis: } \\
\text { when to suspect } \\
\text { empyema }\end{array}$ & $\begin{array}{l}\text { CAP/HCAP not responding to } \\
\text { appropriate antibiotic therapy }\end{array}$ & & & \\
\hline Pleural fluid analysis & $\begin{array}{l}\text { Presence of pus, or Gram stain } \\
\text { positive pleural fluid, or pleural } \\
\text { fluid } \mathrm{pH}<7.2 \text { should indicate } \\
\text { presence of empyema }\end{array}$ & $\begin{array}{l}\text { Pleural fluid } \mathrm{LDH}>1,000 \\
\mathrm{IU} / \mathrm{L}, \text { glucose }<40 \\
\mathrm{mg} / \mathrm{dL} \text {; or presence of } \\
\text { loculations }\end{array}$ & & \\
\hline $\begin{array}{l}\text { Imaging evaluation: } \\
\text { which study to } \\
\text { perform? }\end{array}$ & $\begin{array}{l}\text { CXR and pleural USG to be } \\
\text { done routinely; both for diag- } \\
\text { nostic and for image guided } \\
\text { therapeutic procedures }\end{array}$ & CT should be done in all & & \\
\hline \multicolumn{5}{|l|}{ Acute empyema } \\
\hline $\begin{array}{l}\text { Antibiotic treatment } \\
\text { in acute empyema }\end{array}$ & $\begin{array}{l}\text { Antibiotic should be chosen } \\
\text { based on culture reports, if } \\
\text { available (LOE C) }\end{array}$ & $\begin{array}{l}\text { Intrapleural antibiotic } \\
\text { treatment is not useful } \\
\text { (LOE C) }\end{array}$ & & \\
\hline $\begin{array}{l}\text { Thoracocentesis } \\
\text { without tube place- } \\
\text { ment in acute } \\
\text { empyema }\end{array}$ & & & & $\begin{array}{l}\text { Not } \\
\text { recommended } \\
(\text { LOE C) }\end{array}$ \\
\hline $\begin{array}{l}\text { Image guided drain } \\
\text { placement in acute } \\
\text { empyema }\end{array}$ & $\begin{array}{l}\text { - Helpful in early stages when } \\
\text { there are less number of } \\
\text { septae (LOE B) } \\
\text { - Tube should be regularly } \\
\text { flushed to avoid blockage } \\
\text { (LOE B) } \\
\text { - Follow-up CT and manage- } \\
\text { ment escalation (if needed) } \\
\text { are recommended (LOE C) }\end{array}$ & $\begin{array}{l}\text { In the presence of thick } \\
\text { septae, image guided } \\
\text { tube placement can be } \\
\text { done in patients not } \\
\text { suitable for surgery } \\
\text { (LOE C) }\end{array}$ & & \\
\hline
\end{tabular}


Table 5 (Continued)

\begin{tabular}{|c|c|c|c|c|}
\hline & Recommendations (class I) & $\begin{array}{l}\text { Recommendations } \\
\text { (class Ila) }\end{array}$ & $\begin{array}{l}\text { Recommendations } \\
\text { (class IIb) }\end{array}$ & $\begin{array}{l}\text { Not } \\
\text { recommended } \\
\text { (class III) }\end{array}$ \\
\hline $\begin{array}{l}\text { IPFT in acute } \\
\text { empyema }\end{array}$ & & $\begin{array}{l}\text { Should not be routinely } \\
\text { used in CPE and early } \\
\text { empyema (LOE } A)^{a}\end{array}$ & & \\
\hline $\begin{array}{l}\text { Surgical manage- } \\
\text { ment in acute } \\
\text { empyema }\end{array}$ & & $\begin{array}{l}\text { VATS should be per- } \\
\text { formed in stage-ll acute } \\
\text { empyema (LOE B) }\end{array}$ & & \\
\hline \multicolumn{5}{|l|}{ Chronic empyema } \\
\hline $\begin{array}{l}\text { Chronic empyema: } \\
\text { tube drainage }\end{array}$ & & & $\begin{array}{l}\text { May be considered } \\
\text { in patients with } \\
\text { small chronic } \\
\text { empyema/small } \\
\text { BPF (if unfit for } \\
\text { surgery; LOE C) }\end{array}$ & \\
\hline $\begin{array}{l}\text { Chronic empyema: } \\
\text { decortication }\end{array}$ & & $\begin{array}{l}\text { Should be done in all } \\
\text { patients who can with- } \\
\text { stand the surgical } \\
\text { procedure }\end{array}$ & & \\
\hline Empyema in children & $\begin{array}{l}\text { Should be treated with small } \\
\text { bore tube } \\
\text { thoracostomy first (LOE A; with } \\
\text { or without IPFT) }\end{array}$ & $\begin{array}{l}\text { Thoracoscopic proce- } \\
\text { dure should be per- } \\
\text { formed in cases of non- } \\
\text { response to tube thora- } \\
\text { costomy and IPFT } \\
\text { (LOE B) }\end{array}$ & & \\
\hline
\end{tabular}

Abbreviations: AATS, American Academy for Thoracic Surgeons; BPF, bronchopleural fistula; CAP, community-acquired pneumonia; CPE, complicated parapneumonic effusion; CT, computed tomography; CXR, chest X-ray; HAP, hospital-acquired pneumonia; LDH, lactate dehydrogenase; LOE, level of evidence; USG, ultrasonography; VATS, video-assisted thoracic surgery;

${ }^{a}$ This remains a matter of debate; as several prominent trials (e.g., multicenter intrapleural sepsis trial 2) advocate the use of IPFT to improve outcome and avoid surgery. In practice, it largely depends on multiple factors as follows: (1) institutional protocol; (2) availability of experienced thoracic surgeon for decortication which is a major surgical procedure; (3) availability of appropriate surgical infrastructure, especially in emergency hours; (4) patient suitability for undergoing a major surgical procedure; and (5) experience of the interventional radiology team.

${ }^{\mathrm{b}}$ Choosing an optimum tube size in children is also a controversial topic (discussed in detail above).

\section{Conclusion}

IPFCs, secondary to pyogenic infections, require early complete drainage of the fluid in addition to systemic drugs. Image-guided drainage along with IPFT plays an important role in improving outcomes.

Supplementary Material

Supplementary MaterialSupplementary Materialconflict of interest

There are no financial or nonfinancial conflicts.

\section{References}

1 Light RWPleural Diseases. 6th ed. India: Wolters Kluwer2019

2 Scarci M, Abah U, Solli P, et al. EACTS expert consensus statement for surgical management of pleural empyema. Eur J Cardiothorac Surg 2015;48(05):642-653

3 Zahid I, Routledge T, Billè A, Scarci M. What is the best treatment of postpneumonectomy empyema? Interact Cardiovasc Thorac Surg 2011;12(02):260-264
4 Balfour-Lynn IM, Abrahamson E, Cohen G, et al. Paediatric Pleural Diseases Subcommittee of the BTS Standards of Care Committee. BTS guidelines for the management of pleural infection in children. Thorax 2005;60(Suppl 1):i1-i21

5 Davies HE, Davies RJ, Davies CW, Group BPDGBTS Pleural Disease Guideline Group. Management of pleural infection in adults: British Thoracic Society Pleural Disease Guideline 2010. Thorax 2010;65(Suppl 2):ii41-ii53

6 Shen KR, Bribriesco A, Crabtree T, et al. The American Association for Thoracic Surgery consensus guidelines for the management of empyema. J Thorac Cardiovasc Surg 2017;153(06):e129-e146

7 Colice GL, Curtis A, Deslauriers J, et al. Medical and surgical treatment of parapneumonic effusions : an evidence-based guideline. Chest 2000;118(04):1158-1171

8 Light RW. A new classification of parapneumonic effusions and empyema. Chest 1995;108(02):299-301

9 Pine JR, Hollman JL. Elevated pleural fluid pH in Proteus mirabilis empyema. Chest 1983;84(01):109-111

10 Micek ST, Dunne M, Kollef MH. Pleuropulmonary complications of Panton-Valentine leukocidin-positive community-acquired methicillin-resistant Staphylococcus aureus: importance of 
treatment with antimicrobials inhibiting exotoxin production. Chest 2005;128(04):2732-2738

11 El Solh AA, Alhajjhasan A, Ramadan FH, Pineda LA. A comparative study of community- and nursing home-acquired empyema thoracis. J Am Geriatr Soc 2007;55(11):1847-1852

12 Maskell NA, Batt S, Hedley EL, Davies CW, Gillespie SH, Davies RJ. The bacteriology of pleural infection by genetic and standard methods and its mortality significance. Am J Respir Crit Care Med 2006;174(07):817-823

13 Lin YC, Chen HJ, Liu YH, Shih CM, Hsu WH, Tu CY. A 30-month experience of thoracic empyema in a tertiary hospital: emphasis on differing bacteriology and outcome between the medical intensive care unit (MICU) and medical ward. South Med J 2008;101(05):484-489

14 Ibitoye BO, Idowu BM, Ogunrombi AB, Afolabi BI. Ultrasonographic quantification of pleural effusion: comparison of four formulae. Ultrasonography 2018;37(03):254-260

15 Moy MP, Levsky JM, Berko NS, Godelman A, Jain VR, Haramati LB. A new, simple method for estimating pleural effusion size on CT scans. Chest 2013;143(04):1054-1059

16 Ahmed AE, Yacoub TE. Empyema thoracis. Clin Med Insights Circ Respir Pulm Med 2010;4:1-8

17 Naranje P, Guleria RImaging of infections of pleura and chest wall. In: Bhalla AS, Jana M, eds. Clinicoradiological Series: Imaging of Chest Infections. Delhi, India: JP Brothers Medical Publishers2018:385-404

18 Subotic D, Lardinois D, Hojski A. Minimally invasive thoracic surgery for empyema. Breathe (Sheff 2018;14(04):302-310

19 Andrews NC, Parker EF, Shaw RR, Wilson J, Webb WR. Management of nontuberculous empyema: a statement of the subcommittee on surgery. Am Rev Respir Dis196285:935-936

20 Heffner JE, McDonald J, Barbieri C, Klein J. Management of parapneumonic effusions. An analysis of physician practice patterns. Arch Surg 1995;130(04):433-438

21 Ashbaugh DG. Empyema thoracis. Factors influencing morbidity and mortality. Chest 1991;99(05):1162-1165

22 Corso RM, Agnoletti V, Piraccini E, Lupi C, Gambale G. Wireguided chest tube placement in the intensive care unit. Anaesth Intensive Care 2012;40(06):1071-1072

23 Davies CW, Kearney SE, Gleeson FV, Davies RJ. Predictors of outcome and long-term survival in patients with pleural infection. Am J Respir Crit Care Med 1999;160(5, pt 1)16821687

24 Maskell NA, Davies CW, Nunn AJ, et al.First Multicenter Intrapleural Sepsis Trial (MIST1) Group. U.K. Controlled trial of intrapleural streptokinase for pleural infection. N Engl J Med 2005;352 (09):865-874

25 Rahman NM, Maskell NA, West A, et al. Intrapleural use of tissue plasminogen activator and DNase in pleural infection. $\mathrm{N}$ Engl J Med 2011;365(06):518-526
26 Rahman NM, Maskell NA, Davies CW, et al. The relationship between chest tube size and clinical outcome in pleural infection. Chest 2010;137(03):536-543

27 Havelock T, Teoh R, Laws D, Gleeson F, Group BPDGBTS Pleural Disease Guideline Group. Pleural procedures and thoracic ultrasound: British Thoracic Society Pleural Disease Guideline 2010. Thorax 2010;65(Suppl 2):ii61-ii76

28 Hooper CE, Edey AJ, Wallis A, et al. Pleural irrigation trial (PIT): a randomised controlled trial of pleural irrigation with normal saline versus standard care in patients with pleural infection. Eur Respir J 2015;46(02):456-463

29 Skeete DA, Rutherford EJ, Schlidt SA, Abrams JE, Parker LA, Rich PB. Intrapleural tissue plasminogen activator for complicated pleural effusions. J Trauma 2004;57(06):1178-1183

30 Thommi G, Nair CK, Aronow WS, Shehan C, Meyers P, McLeay M. Efficacy and safety of intrapleural instillation of alteplase in the management of complicated pleural effusion or empyema. Am J Ther 2007;14(04):341-345

31 Heimes J, Copeland H, Lulla A, et al. The use of thrombolytics in the management of complex pleural fluid collections. J Thorac Dis 2017;9(05):1310-1316

32 Popowicz N, Bintcliffe O, De Fonseka D, et al. Dose de-escalation of intrapleural tissue plasminogen activator therapy for pleural infection. the alteplase dose assessment for pleural infection therapy project. Ann Am Thorac Soc 2017;14(06):929-936

33 Redden MD, Chin TY, van Driel ML. Surgical versus non-surgical management for pleural empyema. Cochrane Database Syst Rev 2017;3:CD010651

34 Altmann ES, Crossingham I, Wilson S, Davies HR. Intra-pleural fibrinolytic therapy versus placebo, or a different fibrinolytic agent, in the treatment of adult parapneumonic effusions and empyema. Cochrane Database Syst Rev 2019;2019(10):CD002312

35 Jester I, Nijran A, Singh M, Parikh DH. Surgical management of bronchopleural fistula in pediatric empyema and necrotizing pneumonia: efficacy of the serratus anterior muscle digitation flap. J Pediatr Surg 2012;47(07):1358-1362

36 Pierrepoint MJ, Evans A, Morris SJ, Harrison SK, Doull IJ. Pigtail catheter drain in the treatment of empyema thoracis. Arch Dis Child 2002;87(04):331-332

37 Thomson AH, Hull J, Kumar MR, Wallis C, Balfour Lynn IM. Randomised trial of intrapleural urokinase in the treatment of childhood empyema. Thorax 2002;57(04):343-347

38 Petel D, Li P, Emil S. Percutaneous pigtail catheter versus tube thoracostomy for pediatric empyema: A comparison of outcomes. Surgery 2013;154(04):655-660discussion 660-661

39 Lewis MR, Micic TA, Doull IJM, Evans A. Real-time ultrasoundguided pigtail catheter chest drain for complicated parapneumonic effusion and empyema in children - 16-year, single-centre experience of radiologically placed drains. Pediatr Radiol 2018;48 (10):1410-1416 